\title{
Linguistic Studies
}

Языкознание

DOI 10.31696/2618-7043-2019-2-1-119-133

УДК 811.411.21

Оригинальная статья

Original Paper

\section{Заметка о греческом письме и греческом языке в сочинении арабского автора Х в. Ибн ан-Надйма Кита̄б ал-Фихрист и ее происхождение}

\author{
Н. И. Сериков \\ Институт востоковедения РАН, г. Москва, Российская Федерация, \\ ORCID: https://orcid.org/0000-0003-2760-6312, e-mail: nikolajserikoff@gmail.com
}

Резюме: статья посвящена разделу из Кита̄б ал-Фихрист Ибн ан-Надйма, в котором говорится об истории греческого алфавита. Автор исследует композицию раздела, а также способы передачи греческой лингвистической терминологии средствами арабской графики. На основании полученных результатов он приходит к выводу о том, что этот раздел состоит из нескольких разнородных частей, причем некоторые из них написаны на основании материалов, содержавшихся изначально в сочинении Хунайна ибн Исхака (ум. 873 г. по Р. Х.) «0 правиле и'раба согласно воззрениям греческих ученых».

Киючевые слова: Византия; Ибн ан-Надйм; Кита̄б ал-Фихрист; флексии греческие, и'ра̄б; Хунайн ибн Исхฺак; язык, арабский; язык, греческий

Благодарности: я приношу благодарности моим коллегам, о. А. С. Трейгеру (Канада) и В. Н. Настичу (Москва), внимательно прочитавшим статью и сделавшим ряд весьма полезных замечаний.

Аия цитирования: Сериков Н. И. Заметка о греческом письме и греческом языке в сочинении арабского автора Х в. Ибн ан-Надйма Кита̄б ал-Фихрист и ее происхождение. Ориенталистика. 2019;2(1):119-133. DOI: 10.31696/26187043-2019-2-1-119-133.

\section{A note about the Greek script and the Greek language as found in Kitāb al-Fihrist by Ibn an-Nadīm}

\author{
N. I. Serikoff \\ Institute of Oriental Studies, Russian Academy of Sciences, Moscow, Russian Federation, \\ ORCID: https://orcid.org/0000-0003-2760-6312, e-mail: nikolajserikoff@gmail.com
}

\begin{abstract}
Greek language and the Greek script as found in the Kitab al-Fihrist by Ibn an-Nadim. The author analyses the composition of the passage as well as the ways and methods applied to transcribe the Greek technical linguistic terms with Arabic letters. The results obtained invite a strong suggestion that the note as a whole was not written by Ibn an-Nadim himself but was constructed on the basis of the material from the Greek manual Kitāb fi aḥkām $a l-i^{c} r a ̄ b$ 'alā madhab al-yūnāniyyīn composed by Hunayn ibn Ishaq (d. 873 AD).
\end{abstract}


Key words: Byzantium; Hunayn ibn Ishaq; Ibn an-Nadim; Ihkam al-i'rab 'ala madhab al-yunaniyyin; i'rab, al-; language, Arabic; language, Greek; Kitāb al-Fihrist

Acknowledgements: I am grateful to my colleagues Rev. Prof. A. Treiger (Dalhouise University, Canada) and Dr. V. Nastich (Moscow) for their kind attention to my text as well as for their suggestions, which were thankfully accepted.

For citation: Serikoff N. I. A note about the Greek script and the Greek language as found in Kitāb al-Fihrist by Ibn an-Nadīm. Orientalistica. 2019;2(1):119-133. DOI: 10.31696/2618-7043-2019-2-1-119-133.

\section{Введение}

Сочинение Ибн ан-Надйма «Кита̄б ал-Фихрист» [1] ${ }^{1}$ по праву считается энциклопедией арабской культуры X в. по Р. Х. Уникальность содержащихся там сведений далеко не единожды привлекала внимание ученых. Однако, несмотря на это, в сочинении еще много «темных мест». Не в последнюю очередь к таковым относятся источники «Кита̄б ал-Фихрист», что неудивительно. До сих пор это является одной из наименее исследованных областей, так как многие книги, использованные Ибн ан-Надймом для написания своего уникального биобиблиографического труда², до нашего времени не дошли.

В полной мере сказанное относится к заметке о греческом языке и греческом письме, помещенной в самом начале Кита̄б ал-Фихрист [1, 1 15.4-16.6]. Происхождение этой заметки до сих пор не объяснено, за исключением некоторых глосс, откомментированных еще издателями памятника в 1871-1872 гг. Цель настоящей статьи - выявить источники этой заметки и тем самым пролить дополнительный свет на степень знакомства средневековых арабов с византийской культурой, в частности с их взглядами на происхождение греческого языка и способом его описания. Последнее напрямую связано с тем, как арабы видели и изучали язык своего самого главного соседа и противника, - аспект, лишь частично затронутый современной наукой.

\section{Текст заметки "О письме ромеев" В переводе на русский язык Kitāb al-Fihrist 1 15.4-16.6}

1. В некоторых старинных исторических сочинениях я прочитал, что греки в древности не знали письма до тех пор, пока из Египта не пришли два мужа, одного из которых звали Кймус ${ }^{3}$, а другого Аеุнȳp ${ }^{4}$, и не принесли с собою 16 букв. При помощи этих букв греки стали писать. Потом один из них изобрел еще четыре буквы, которые также стали употреб-

\footnotetext{
1 Далее в тексте: Kitāb al-Fihrist.

2 О целях и задачах, которые ставил перед собой Ибн ан-Надим, см.: [2].

3 Имеется в виду Кадм, сын финикийского царя Агенора [3].

${ }^{4}$ См. предыдущее примечание. Рукопись, использованная для английского перевода Б. Доджем, дает «Аг्нӯн»: [4].
} 
лять для письма. Затем некто по имени Самунйдус ${ }^{5}$ изобрел следующие четыре, и [всех] букв стало числом двадцать четыре. В это время жил Сукра̄тฺис ${ }^{6}$ о чем упомянул монах Исхака ${ }^{7}$ в своей истории.

2. Я спросил ромея, [обратясь] к нему на их языке (а он сообщал о себе, что [в образовании своем] он дошел до уровня называемого

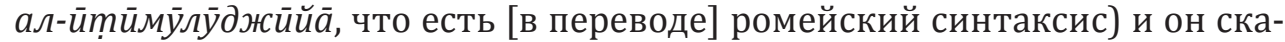
зал, что это общеизвестный факт, что в Городе Мира ${ }^{8}$ ромеи использова-

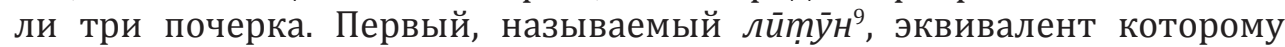
у арабов - «шрифт библиотекарей» и которым переписывают Коран. Почерком лӣmȳ̄н писали свои богослужебные книги также и греки. (Эти люди у ромеев объединялись в сословие и назывались йрийа̄, т.е. ${ }^{10}$ «священник».) Почерк выглядит следующим образом ${ }^{11}$.

И еще у них также есть почерк, именуемый $а ф \bar{y} \varnothing \varnothing \bar{и} б \bar{a} \partial \bar{y} H^{12}$, а равно-

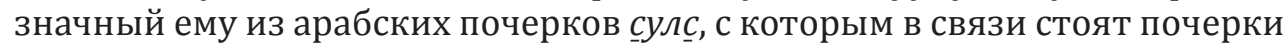
мухаккак ${ }^{13}$ и мусаххал. Почерк выглядит следующим образом ${ }^{14}$.

У них также есть почерк, называемый $c \bar{p} p \bar{n} \bar{y} H^{15}$, а это облегченный почерк [греческих] писцов. У нас ему равнозначен [почерк] тарсйл дйвй$н \bar{u}$ и буквы в нем пишутся схоже, а вот его образец ${ }^{16}$.

3. А помимо этого, у них есть почерк, именуемый $a c$-са̄мūŭ $\bar{a}^{17}$, а равнозначного почерка у нас нет. Одна его буква имеет много значений и объединяет целый ряд слов. В «Пинаксе» своих книг (а значение этого слова «порядок книг» ${ }^{18}$ ) Гален о нем написал так: «Я был в собрании и читал там обобщающую лекцию об анатомии. А спустя несколько дней

${ }^{5}$ Симонид Кеосский, греческий лирический поэт ок. 557/556-468/7 до Р. Х.

${ }^{6}$ Сократ (470-399 до Р. Х.), известнейший греческий философ, личность весьма хорошо знакомая арабам, к которой было легко «привязывать» современников, ср.: [5].

7 Сочинения этого автора до наших дней, кажется, не дошли. 0 нем говорит только Ибн ан-Надим в «Кита̄б ал-Фихрист».

8 Имеется в виду Багдад.

9 Комментарий см. ниже.

${ }^{10}$ Стоящее в переводе «т.е.» это араб. $\mathbf{~} ;$ вставлено первыми издателями Кита̄б алФихрист, ср. перевод: «Und diese Schrift heißt gewöhnlich die ípó der Griechischen Confession, d.h. "die heilige”». Перевод Б. Доджа зависит от немецкого: «It is known as Îriyā, for the Greek

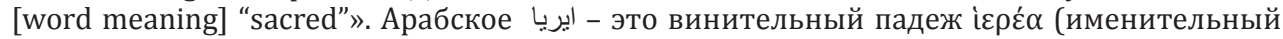

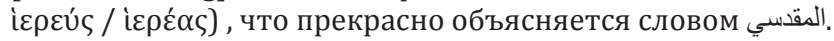

11 Образец почерка в тексте Кита̄б ал-Фихрист отсутствует.

12 Комментарий см. ниже.

13 Конъектура издателя.

14 Образец почерка в тексте Кита̄б ал-Фихрист отсутствует.

15 Комментарий см. ниже.

16 Образец почерка в тексте Кита̄б ал-Фихрист отсутствует.

17 Комментарий см. ниже.

18 О значении слова фихрист см.: [6]. 
встретился мне мой близкий друг и сказал, что некто записывал, что я говорил в собрании: “а сказал ты то-то и то-то”. И повторил мои слова слово в слово. На мой вопрос, “откуда ты все это взял?”, он сказал: “я встретился с писцом, искушенным в почерке $a c-c \bar{a} м \bar{u} и \bar{a}$ и он писал им так быстро, что [даже] опережал тебя, [хотя ты и говорил]”»19. (А этот почерк изучали цари и самые важные из писцов. А прочие люди к изучению этого почерка не допускались из-за его величия.)

4. В 48 году ${ }^{20}$ к нам прибыл медик-практик из Баальбека, который утверждал, что он может писать почерком $a c$-са̄мūŭā, и мы на деле проверили все то, о чем он рассказывал. Он нас поразил тем, что когда мы сказали десять слов, он их внимательно выслушал и написал [всего] одно. Когда же мы попросили его повторить, он повторил сказанное слово в слово.

5. Цитата из Джа'фара ибн-Муктафй ${ }^{21}$ : «Причина, по которой ромеи пишут слева направо. Они полагают, что при любых обстоятельствах сидеть надо лицом к востоку. Сидящий лицом к востоку имеет север слева, а левое подчинено правому. Поэтому пишущий “начинает” с севера и “идет” на юг».

6. Другая цитата: «У ромеев есть законы и установления в письме. И предписания эти суть следующие: Есть среди двадцати четырех букв

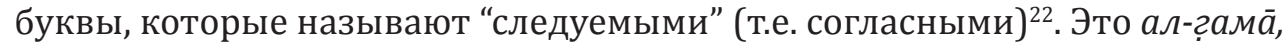

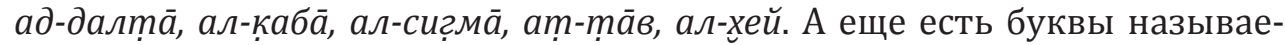

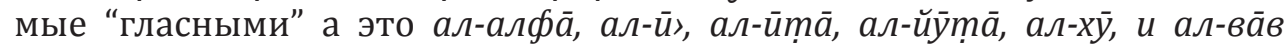

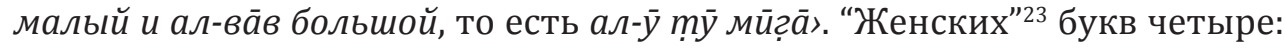

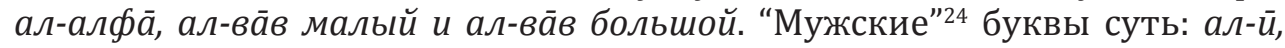

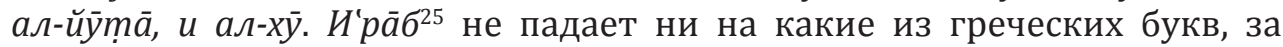
исключением семи гласных букв, которые называются "ал-ладжайн"26. Греческий язык обходится без шести букв языка арабского, каковы суть

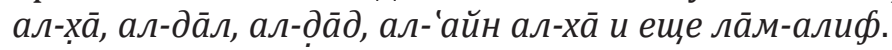

\section{Композиция заметки}

Занимающая всего одну страницу современного издания заметка Ибн ан-Надйма составлена из выдержек как минимум из шести источников, бывших в его распоряжении. Они суть следующие. 1. Некие «старин-

19 Пересказ греческого текста, комментарий см. ниже.

20 То есть 959 Р. Х., как считает Б. Додж.

21 Абу-л-Фадл Джа'фар ибн ал-Муктафй (906-977 Р.Х.) - сын или брат аббасидского халифа ал-Муктафй билла̄ха (ок. 876-908 Р. Х.), широко образованный человек, знавший математику, философию и астрономию, в частности описавший пятна на солнце [7, p. 161].

22 Комментарий см. ниже.

23 То есть окончания существительных женского рода, комментарий см. ниже.

24 То есть окончания существительных мужского рода, комментарий см. ниже.

25 Арабский грамматический термин, означающий изменение в конечной позиции слова в зависимости от изменения синтаксических конструкций.

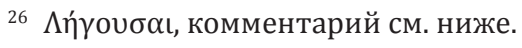


ные исторические сочинения», выписки из которых собственноручно сделал Ибн ан-Надйм [1, 1 15.5]. 2. Сведения, взятые автором (или его информантом ${ }^{27}$ ) у образованного византийца, жившего в Х в. в Городе Мира [1, 1 15.9] (т.е. Багдаде). 3. Выдержка из перевода на арабский «Пинакса» Галена [1, 1 15.19]. 4. Собственные впечатления [1, 1 16.5] о том, как владел греческой скорописью некий практикующий врач в «48 году» прибывший в Багдад (?) из Баальбека. 5. Выдержка из утерянного сочинения Джафара ибн ал-Муктафй о направлении греческого письма. 6. Классификации греческих букв и заметки об их использовании в окончаниях греческих слов.

Сведения, приведенные в этой компиляции, не структурированы и не отредактированы. Они вводятся маркерами «сказал» (ка̄ла) и « прочитал».

\section{Источники и комментарии}

1. С точностью источник определить пока не удалось. Известия о том, что Кадм и другие дали грекам финикийские буквы (Pauly RE I/2 P. 1612), встречается и в других арабских сочинениях, в частности в «Книге Пирамид» ал-Идрйсй [8, S. 565] (ум. 649 Г.Х. (1251 по Р. Х.)) и в компиляции XVII в. Макария аз-За'йма, патриарха Антиохийского [9, с. 297-307]. Источник этих сведений, скорее всего арабский, в свою очередь основывался на главных сочинениях, использовавшихся в византийском образовании - «Ремесле грамматика» Дионисия Фракийца (ок. 170-90 до Р. Х.) и комментариях на него, а также сочинениях Георгия Хировоска [10, p. 252; 11, p. 865], в данном случае, его «Канонах» [12]. Известно, что текст Дионисия достаточно рано был переведен на сирийский [13]28. Обыкновенно этот перевод приписывают сирийскому грамматисту VI в. по Р. Х. Хузайе. Изданный А. Мерксом текст сирийского перевода не содержит, однако, раздела по истории греческого алфавита. Причин этому выяснить не удалось, но представляется, что этот раздел был просто не нужен сирийскому грамматисту: сирийцы не использовали греческих букв. Аналогичного мнения придерживаются и другие современные ученые, исследовавшие этот памятник [14, р. 176]. Поэтому, скорее всего, источник Ибн ан-Надйма был греческий. Примечательно, что в других традициях, где использовали греческие буквы (или построенные на их основе свои собственные), этот текст, напротив, присутствует. В частности, он практически повторен у болгарского автора Х в. по Р. Х. Черноризца Храбра [15] ${ }^{29}$.

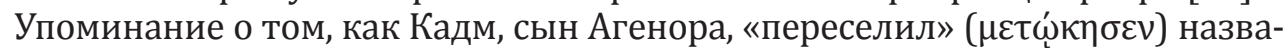
ния финикийских букв в Элладу, т.е. стал называть греческие буквы на

27 См. комментарий.

28 Из недавних см.: [14].

29 См. также комментарий Б. Н. Флори к московскому списку XV в.: www.vostlit.info/ Texts/Dokumenty/Tschechien/IX/Slav_pis/frametext3.htm, прим. 30. 
финикийский лад («алф-а», «далт-а» и т.п.), встречается в «Канонах» Хировоска (Choerobosci Canones II 369.15), цитата которого восходит также к Геродоту (Herod. 5.58). На основании греческого текста видно, что араб-

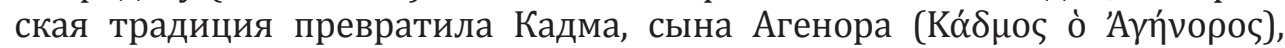
в двух человек: «Кадма и Агенора». Эта особенность укоренилась в арабской традиции и оставалась в ней без изменения вплоть до XVII в.

Сочинение «История монаха Исаака», на которое Ибн ан-Надйм ссылается ниже, до нашего времени не дошло, и восстановить его даже примерно не удалось.

2. Информация, полученная Ибн ан-Надймом от «образованного ромея», уникальна. Это единственное известное мне в арабской литературе место, где приведена номенклатура греческого письма. Встает, однако, вопрос: кто, собственно, опрашивал ромея, и откуда был он родом. Соответствующая арабская фраза не поддается однозначному толкова-

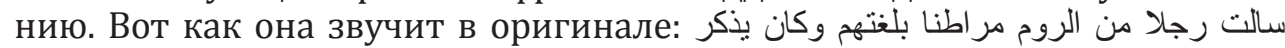
вразу можно истолковать двояко: а) следуя издателям памятника, в форме الناط т.е. позицию состояния субъекта действия (سالت). В этом случае перевод будет звучать, как «я спросил на иностранном языке [т.е. по-гречески]». Следуя за этим переводом, мы получаем все основания предположить, что Ибн ан-Надйм знал по-гречески настолько хорошо, чтобы опрашивать информантов и самому разбираться в тонкостях византийской каллиграфии. Однако нигде более этот факт не находит подтверждения. Более того, перевод слова «этимология» как «грамматика» (النحو) хотя и имеет под собою значительные основания (об этом см. ниже), таковым, строго говоря, не является. Сказанное позволяет усомниться в способностях Ибн ан-Надйма говорить по-гречески и читать на этом языке; б) усматривая в مراطناط маф'уул бихи, т.е. так называемый винительный падеж прямого дополнения. В этом случае перевод кардинально меняется: «Я опросил некоего ромея, который говорил на их языке». Тогда перед нами другое интересное свидетельство, где речь идет о ромее - носителе греческого языка, получившем «университетское» образование. Еще более замечателен тот факт, что этот «ромей» комментирует особенности греческой каллиграфии в том виде, в каком она была распространена в «городе Мира», т.е. Багдаде. Подобное прочтение является также достаточным основанием для предположения о том, что во времена Ибн ан-Надйма в Багдаде действовал греческий скрипторий и что культура греческого письма была там на весьма высоком уровне. Однако, как и в предыдущем случае, этот факт не находит прямого подтверждения в независимых источниках, хотя о существовании так называемого ромейского квартала в Багдаге достоверно известно $[16-20]^{30}$. На мой взгляд, ситуация становится яснее, если

30 Я благодарен А. С. Трейгеру, указавшему мне на эти работы. 
предположить, что Ибн ан-Надйм просто переписал эту фразу из какого-то другого источника. Содержание всего абзаца, и в частности этой фразы, недвусмысленно указывает на то, что она происходит из какого-то учебного текста, в котором говорилось о типах греческого письма (ср. выше параграф об истории греческого алфавита). Единственный из известных учебников греческого языка, существовавших во время Ибн ан-Надйма на арабском языке, - сочинение Хунайна ибн Исхака «О правиле и'раба согласно воззрениям греческих ученых» [21]. Оно написано на основании современных византийских сочинений (Георгий Хировоск), а также в какой-то степени на основании собственного опыта Хунайна. Поэтому оно вполне могло содержать отсылки к различного рода информантам, среди которых мог оказаться и «образованный ромей». В пользу того, что перед нами не самостоятельная заметка Ибн ан-Надйма, а выписка из Хунайна ибн Исхฺка, говорит и помещенная ниже глосса. Сообщая об уровне образованности «ромея», Ибн ан-Надйм, в частности, замечает, что тот, «по его собственным словам, в изучении [греческого] достиг уровня, называемого ал-ӣmūмȳлӯджийа̄, что есть [в переводе]

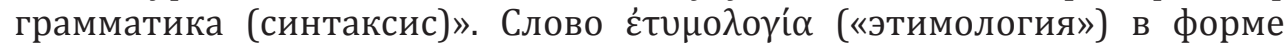
ал-йтฺймӯлӯджйа̄ было известно арабам и сирийцам уже в Х в. В словаре Бар Бахлӯла оно толковалось как «имена производные» (الاسما المشتقة) $[22,124.24-125.2]^{31}$. Образованный византийский читатель, напротив, видел в «этимологии» прием, направленный на объяснение одного из аспектов грамматики - правописания. Наряду с «этимологией» он включал также аналогию, диалектные особенности и историю слов. Об этом говорится в первую очередь у Дионисия Фракийца [23, р. 44; 24, p. 93, not 17], а также у опиравшегося во многом на его сочинение автора учебника греческого языка Х в. по Р. Х. Георгия Хировоска. Последний, в част-

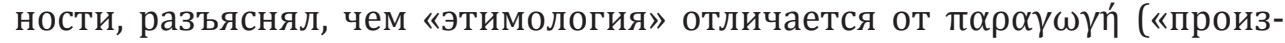
водности» или «словопроизводства»). Он писал, что «производность» принимает во внимание лишь начальные части слова, в то время как «этимология» рассматривает как начальную, так и конечную части слова

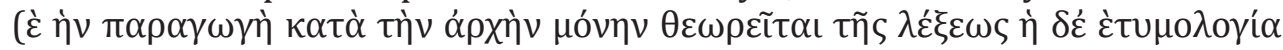

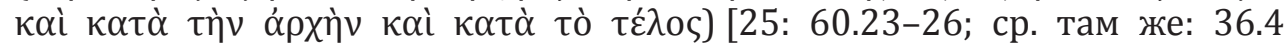
и 89.22-24]. Конечно, объяснение слова «этимология» как «грамматика» нельзя считать неверным, но сама возможность такого толкования требовала от Ибн ан-Надйма недюжинных познаний не только в области арабского, но также в области греческого и сирийского языков. В отношении этого применительно к Ибн ан-Надйму сведений не сохранилось. Не видно это и на основании текста Кита̄б ал-Фихрист. Поэтому отнесение данного пассажа на счет Хунайна ибн Исхฺка не представляется чем-то

31 Причем автор иллюстрировал глоссу разъяснением имени собственного $M \bar{y} c \bar{a}$ (Моисей). В его основе согласно византийской историографической традиции, лежало слово «вода» (в том смысле, что Моисей младенцем был спасен из воды дочерью Фараона). 
из ряда вон выходящим. Последующие строки, где говорится о типах греческого письма, также могут представлять собой испорченную цитату из утраченного сочинения Хунайна. На основании работ В. Гардтхаузена [26]

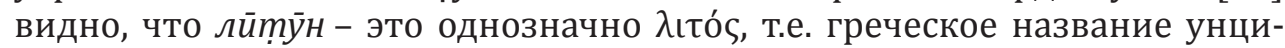

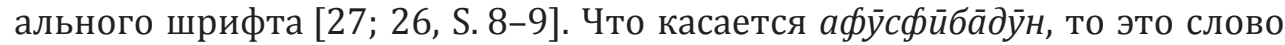
убедительному толкованию не поддается. Предложенное издателями в 1872 г. и повторенное сто лет спустя Б. Доджем толкование «бустрофедон» критики не выдерживает. Такому толкованию противоречит уже приведенное сравнение с арабским почерком ㄷл드, которым никогда не писали в двух направлениях. Основываясь на приведенных издателем разночтениях остается предположить, что под словом-призраком

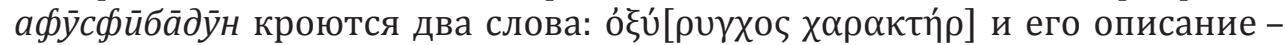

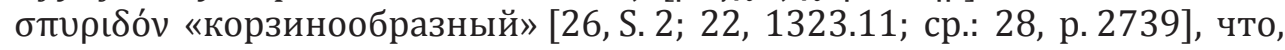
кстати, сближает его с арабским почерком мух⿱㇒кূূর, с которым сравнивает его Ибн ан-Надйм. Что касается «облегченного» почерка сӯpūm̄ȳн, также упомянутого «образованным ромеем», то его определить также нельзя, и место видится испорченным. Сравнивая это описание с предыдущим, можно видеть, что суррйтӯн - не название почерка, а только способ его описания. В этом случае под сӯрūm̄ȳн могут крыться два

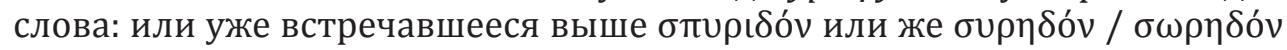
«кучно», как, в частности, комментирует американский переводчик Б. Додж. Учитывая, однако, что употребления этих наречий применительно к описанию шрифтов не зафиксировано, приходится последнее

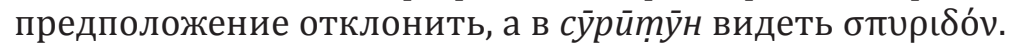

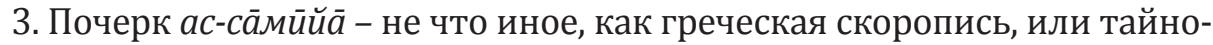
пись $(\sigma \eta \mu \varepsilon \tilde{\alpha} \alpha)$, т.е. «значки» [26, S. 2]. Помимо цитаты из сочинения Галена «о моих собственных книгах», на которую ссылается, в частности, Томпсон [29, р. 60] ${ }^{32}$, глосса, объясняющая его как «сокращенный греческий почерк», содержится в словаре Бар Бахлӯла [22, 1342.17] (cf.: [28, 2416]).

32 Пассаж из оригинального сочинения Галена у Ибн ан-Надима значительно сокращен (см. ниже). Сравнить с переводом на арабский язык Хунайном не представилось возможным. Текст см.: [30, 14.3-15.3] или: [31, р. 138.21-139.13, § 11-13]. Перевод ниже дан по последнему изданию. «Как-то раз, когда я читал на публике лекцию о сочинениях древних врачей, мне протянули трактат Эрасистрата о кровопускании с воткнутым в него, как это принято, стилем, которым отмечалось то место книги, в котором автор осуждает кровопускание. Я пространно порассуждал об этом, чтобы огорчить Мартиалия, который притязал на то, чтобы быть приверженцем Эрасистрата. Поскольку моя лекция была достаточно хорошо встречена, один из моих друзей, который терпеть не мог Мартиалия, убедил меня продиктовать то, что я говорил, некоему присланному от него человеку, умеющему быстро писать значками. Это было сделано для того, чтобы в случае, если мне надо будет уехать из Рима домой, то он смог бы сказать все это Мартиалию во время его визитов к пациентам. После того, не знаю, как случилось, но я во второй раз опять оказался в Риме, будучи призванным императорами. Человек, получивший копию моей лекции, уже умер, но книга, составленная в пылу соперничества (когда я публично опровергал противника), была уже известна немалому числу людей». 
4. Рассказ о заезжем враче не находит параллели в других источниках и поэтому может быть смело отнесен на счет собственных впечатлений Ибн ан-Надйма или его источника, если только под «сорок восьмым годом», следуя за Б. Доджем, понимать 348 Г. Х., на который приходился 959 г. по P. Х. Логика американского переводчика очевидна: дата «подогнана» под годы жизни Ибн ан-Надйма (ум. в 380 Г. Х. (990 по Р. Х.)). Однако никто не мешает видеть в «сорок восьмом годе» 248 Г. Х. (862 г. по Р. Х.), который тогда будет приходиться на годы жизни Хунайна ибн Исхฺка (ум. в 259 Г. Х. (873 по Р. Х.)). Небольшая, но важная деталь: «практикующий врач», ал-мутатпаббиб, мог быть скорее информантом не Ибн ан-Надйма, но именно Хунайна ибн Исхака, который учился медицине и был связан с переводами медицинских текстов с арабского на греческий всю свою жизнь.

5. Цитата из неизвестного и не дошедшего до нас целиком сочинения Джа'фара ибн-Муктафй, сына халифа ал-Муктафй, равно как и следующая за ней, анонимная, представляют значительный интерес. Определить происхождение первой цитаты, объясняющей направление греческого письма (слева направо, тогда как арабы писали справа налево), не представляется возможным.

6. Здесь опять налицо отрывки из сочинения «Грамматического искусства» александрийского автора Дионисия Фракийца ${ }^{33}$. Подобно отрывку из сочинения Галена «0 моих книгах» ${ }^{34}$, текст Дионисия, в том виде, как его приводит Ибн ан-Надйм, сильно сокращен, так что теряется его изначальный смысл ${ }^{35}$. Тем не менее он сохранил очень важные детали.

А. Согласные буквы, которые в арабском тексте называются «следуемыми». «Следуемые» - буквальная передача греческой цитаты из Дионисия: «они названы "со-гласными”, так как сами по себе они не передают голос, но, будучи сопряженными с гласными, они образуют голос» ${ }^{36}$.

Б. «Женские» буквы, т.е. буквы, на которые оканчиваются существительные женского рода, также отмечены Дионисием: «букв, на которые оканчиваются существительные женского рода, суть восемь...».

В. «Мужские» буквы, т.е. буквы, на которые оканчиваются существительные мужского рода: «букв, на которые оканчиваются равносложные существительные мужского рода в именительном и родительном падежах, суть пять».

Арабизированные названия греческих букв, о которых говорится у Ибн ан-Надйма, свидетельствуют о том, что они взяты из арабского,

${ }_{33}$ См. Приложение 1.

34 См. выше.

35 См. соответствующие места в прилагаемом переводе отрывков сочинения Дионисия Фракийца.

36 Это место было неправильно понято первыми издателями «Кита̄б ал-Фихрист»: "Unter al-huruf al-muta'aqiba sind die im Arabischen unmöglichen unmittelbaren Consonantenverbindungen $\gamma \delta, \xi$, ( $\kappa \sigma), \sigma \tau, \sigma \chi$ zu verstehen". 
а не греческого источника. Особенно показательны в данном случае ал-вавв малый (омикрон) и ал-ва̄в большой, т.е. омега (ал-ва̄в малый

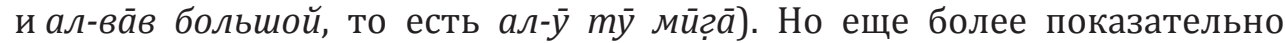
слово, звучащее по-арабски как ал-ладжайн (اللجين) [1, 1.15-16]. Б. Додж ошибочно видел в нем $\lambda \dot{\gamma} \gamma \varepsilon เ \nu$ «говорить», тогда как первые издатели «Кита̄б ал-Фихрист» совершенно правильно увидели в испорченном слове греческий корень $\lambda \eta \gamma$ от $\lambda \eta \dot{\gamma \varepsilon เ v ~ « з а к а н ч и в а т ь », ~ п о с л е ~ т о г о ~ к а к ~ о н о ~}$ было соотнесено с арабским и'ра̄б, т.е. изменением в конечной позиции слова в зависимости от изменения синтаксических конструкций. Собственно, речь идет о $\lambda \eta ́ \gamma о v \sigma \alpha \iota ~ \sigma u \lambda \lambda \alpha \beta \alpha i ́$, т.е. конечных слогах слов, которые изменялись при склонении и спряжении.

Цитата «и'ра̄б не падает ни на какие из греческих букв, за исключением семи гласных букв, которые называются ал-ладжайн», говорит о том, что, в отличие от арабского языка, греческий язык не имеет первичных и вторичных знаков, т.е. букв и огласовок [32, с. 123] для изменения слов в конечной позиции.

\section{Закиючение}

Отмеченные особенности заметки Ибн ан-Надйма показывают, что материалы для нее были позаимствованы из какого-то пособия, предназначенного если не для обучения арабов греческому языку, то, по крайней мере, для объяснения им разницы между греческим и арабским языками. Обилие греческих транслитераций и редких «калек» с греческого говорит о том, что текст был переведен или с сочинения Дионисия Фракийца «Грамматическое искусство», или с позаимствовавшего оттуда многое текста Георгия Хировоска, который являлся основным учебником греческого языка в Византии. Наличие прямой ссылки на арабский перевод сочинения Галена «0 моих книгах», бытовавшего в переводе Хунайна ибн Исхฺқа, а также упоминание о том, что информант Ибн ан-Надйма бегло говорил по-гречески и был знаком с греческой грамматической терминологией, позволяют осторожно предположить, что перед нами отрывки из недошедшей до нас греческой грамматики Хунайна, бытовавшей под названием «О правиле и'раба согласно воззрениям греческих ученых». Предположение подкрепляется тем, что сочинения Георгия Хировоска, как я стремился показать в другом месте [21], явились тем материалом, на котором Хунайн построил свой дидактический труд.

\section{Приложение}

Перевод на русский язык главы 6 про буквы из сочинения Дионисия Фракийца «Грамматическое искусство». Techne Grammatike § 6, с. 12-16.5.

Про минимальные элементы. Букв всего двадцать четыре, начинаются с альфы, а заканчиваются омегой. Буквами (т.е. «процарапываниями» $\gamma \rho \alpha ́ \alpha \mu \alpha \tau \alpha)$ 
они называются, потому что образуются путем царапания или прочерчивания, так как, по словам древних, «писать» означало «царапать»: «Ты, у меня лишь

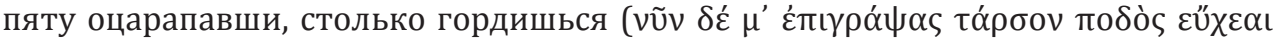

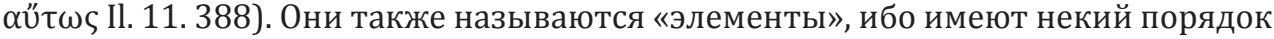
и последовательность.

Среди этих букв суть семь гласных: $\alpha \varepsilon \eta$ เ о и и $\omega$. Они называются гласными, так как они обозначают голос, например, ааа, эээ. Из гласных есть две долгие $\eta$ и $\omega$, две краткие $\varepsilon$ и о и три «двойные», т.е. $\alpha$, เ и v. Они получили название «двойных», так как могут как удлиняться, так и сокращаться. Так называемых прибавляемых спереди гласных суть пять: $\alpha \varepsilon \eta$ о и $\omega$. Они называются «прибавляемыми спереди», так как будучи поставленными перед ı и v образуют слог, как, например, $\alpha$ или $\alpha v$. Так называемых прибавляемых сзади гласных тоже две: เ

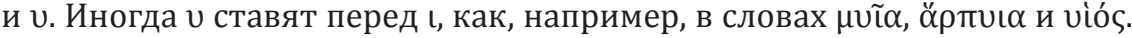

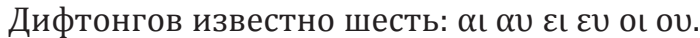

Согласными называются остальные семнадцать $\beta \gamma \delta \zeta \theta \kappa \lambda \mu \nu \xi \pi \rho \sigma \tau \varphi \chi$ భ. Они названы «со-гласными», так как сами по себе они не передают голос, но, будучи сопряженными с гласными, они образуют голос. «Полугласных» из них суть восемь: $\zeta \xi \psi \lambda \mu \nu \rho \sigma$. Они названы полугласными, так как хуже, чем гласные, дают голос, а только в мычании, бормотании и свисте. Безгласных суть девять: $\beta \gamma \delta \kappa \pi \tau \theta \varphi \chi$. Они называются безгласными, так как более других неблагозвучны, подобно тому, как безгласным мы называем актера. Из них «лысых» три к $\pi \tau$, густых три $\theta \varphi \chi$ и три «средних» $\beta \gamma \delta$. «Средними» они называются потому, что более густые, нежели «лысые» и более «лысые», нежели густые. $\beta$ стоит между к и $\chi$, а $\delta-$ между $\tau$ и $\theta$.

Густые противостоят «лысым», т.е. п противостоит $\varphi$, например: «Ты же

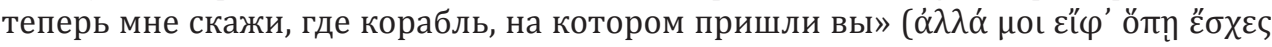

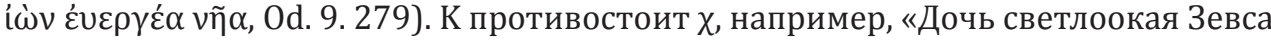
Афина тогда Одиссея...» ( тивостоит $\tau$, например, «Рек он; ахейцы безмолвные все сохраняли молчанье”

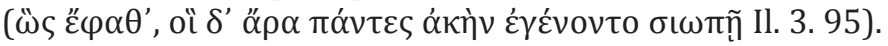

Среди согласных есть три двойных: $, \xi, \psi$. Их называют «двойными», так как каждая из них состоит из двух согласных. Z состоит из $\sigma$ и $\delta$, $\xi$ состоит из к и $\sigma$, а $\psi$ из $\pi$ и $б$.

Также четыре «неизменяемых», как то: $\lambda, \mu, v, \rho$. Они называются «неизменяемыми», так как остаются неизменными при образовании будущего времени у глаголов, равно как и в склонении существительных. Их еще называют «жидкими».

Букв, на которые оканчиваются равносложные существительные мужского рода в именительном и родительном падежах, суть пять: $\omega, \xi, \rho, \sigma, \psi$, как то: Дион

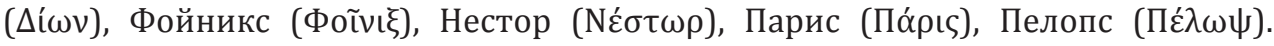
А букв, на которые оканчиваются существительные женского рода, суть восемь:

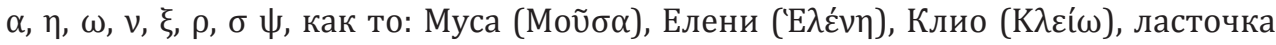

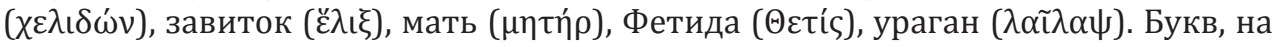
которые оканчиваются существительные среднего рода, суть шесть: $\alpha, \mathrm{l}, v, \rho, \sigma$,

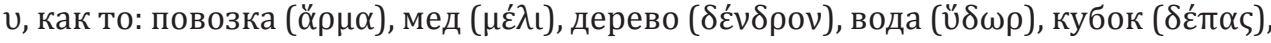


копье ( $\delta$ ó $\rho)$. Некоторые прибавляют о, как то: другое ( $\alpha \lambda \lambda$ ). Окончаний двойственного числа три: $\alpha \varepsilon \omega$. Окончаний множественного числа четыре: $\iota, \sigma, \alpha \eta$,

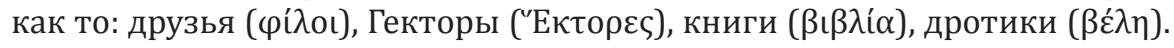

\section{ヘитература}

1. Kitāb al-Fihrist. Mit Anm. hrsg. von Gustav Flügel. Nach dessen Tode besorgt von Johannes Roediger und August Mueller. Leipzig, 1871-1872.

2. Сериков Н. И. Почему Ибн ан-Надим взялся за составление «Кита̄б ал-Фихрист»? В: Седов А. В. (ред.). Исследования по Аравии и исламу: сборник статей в честь 70-летия Михаила Борисовича Пиотровского. М.: ГМВ; 2014. C. $456-473$.

3. Ярхо В. Н. Кадм. В: Токарев С. А. (ред.). Мифы народов мира. М.: Советская энциклопедия; 1987. Т. 1. С. 607.

4. Bayard Dodge. The Fihrist of al-Nadim: A Tenth-Century Survey of Islamic Culture. New York: Columbia University Press; 1970.

5. Alon I. Socrates in Medieval Arabic Literature. Leiden: Bril; 1991.

6. Сериков Н. И. Что означает заглавие сочинения Ибн ан-Надима «Кита̄б ал-Фихрист»? Об одной неизвестной греческо-арабской параллели. В: Дзевановский-Петрашевский В. М. (ред.). Подарок ученым и утешение просвещенным: сборник статей, посвященный 90-летию профессора А. А. Долининой. СПб.: Петербургское востоковедение; 2016. С. 41-61.

7. Yau K. C. Analysis of pre-telescopic and telescopic sunspot observations. In: Stephenson F. R., Wolfendale A. W. (eds). Secular Solar and Geomagnetic Variations in the last 10000 years. Durham; 1987.

8. Das Pyramidenbuch des Abu Ga`far al-Idrisi, eingel. und kritisch hrsg. v. U. Haarmann. Beirut; 1991 (BTS 38) 63.1 cp. ZDMG 13(1859).

9. Сериков Н. И. Слова со скрытым значением. Из «Записной книжки» патриарха Макария Ибн аз-За`има. Христианский Восток. 2001;3(IX):297-307.

10. Lemerle P. Le premier humanisme byzantin: notes et remarques sur enseignement et culture à Byzance des origines au Xe siècle. Paris; 1971.

11. Kazhdan A. (ed.). Oxford Dictionary of Byzantium. Oxford; 1991.

12. Gainsford T. (ed.). Georgii Choerobosci Dictata in Theodosii Canones, Necnon Epimerismi in Psalmos. Vol. 1. Oxford; 1842.

13. Merx A. Historia artis grammaticae apud Syros. Leipzig; 1889.

14. Farina M. Diathesis and middle voice in the Syriac ancient grammatical tradition: The translations and adaptations of the Téchne Grammatiké and the Arabic model. Aramaic Studies. 2008;6(2):175-193. DOI: 10.1163/147783508X393039.

15. Jagić Y. Codex slovenicus rerum grammaticarum. Berlin; 1896.

16. Messina G. Al-Biruni and the Beginning of Christianity at Merv. Indo-Iranica. 1952;5(4):49-56.

17. Parry K. Byzantine-Rite Christians (Melkites) in Central Asia in Late Antiquity and the Middle Ages. Modern Greek Studies. 2012;16:91-108.

18. Klein W. Das orthodoxe katholikat von Romagyris in Zentralasien. Parole de l'Orient. 2010;24(1999):235-265. 
19. Brock S. Two Letters of the Patriarch Timothy from the Late Eighth Century on Translations from Greek Arabic Science and Philosophy. 1999;9(2):233-246. DOI: 10.1017/S0957423900001338.

20. Treiger A. Palestinian Origenism and the Early History of the Maronites: In Search of the Origins of the Arabic Theology of Aristotle In: Janos D. (ed.). Ideas in Motion in Baghdad and Beyond: Philosophical and Theological Exchangesbetween Christians and Muslims in the Third/Ninth and Fourth/Tenth Centuries. Leiden; 2015. Pp. 44-80.

21. Сериков Н. И. Источник и автор глагольных лемм «Лексикона» Бар Бахлула и утерянное сочинение Хунайна ибн Исхака «О правиле и раба согласно воззрениям греческих ученых». Ориенталистика. 2018;1(1):45-65. DOI: 10.31696/2618-7043-2018-1-1-45-65.

22. Hassan bar Bahlul. Lexicon Syriacum. Parisiis; 1901.

23. Robins R. H. The Byzantine Grammarians. Their Place in History. Berlin; New York; 1993.

24. Versteegh C. H. M. Greek Elements in Arabic linguistic thinking. Leiden; 1977.

25. Gainsford T. (ed.). Georgii Choerobosci Dictata in Theodosii Canones, Necnon Epimerismi in Psalmos Vol. 3. Oxford; 1842.

26. Gardthausen V. Die Namen der Griechischen Schriftarten. Byzantinischneugriechische Jahrbücher. 1922;3:1-15.

27. Trapp E. Lexikon zur byzantinischen Gräzität. Byzantinische Zeitschrift; 2007.

28. Payne Smith R. (ed.). Thesaurus Syriacus. Oxford; 1879.

29. Thompson E. M. An Introduction to Greek and Latin palaeography. Oxford; 1912.

30. Kuehn C. G. (ed.). Galeni Opera Omnia. Vol. 19. Lipsiae; 1830.

31. Boudon-Millot V. Galien. Tome I. Introduction générale. Sur l'ordre de ses propres livres. Sur ses propres livres. Que l'excellent médecin est aussi philosophe. Texte établi, traduit et annoté par V. B.-M. Paris: Les Belles Lettres; 2007.

32. Лебедев В. В. Арабская грамматика. Базовый курс на русском и арабском языках. М.: Муравей; 2003.

\section{References}

1. Kitāb al-Fihrist. Mit Anm. hrsg. von Gustav Flügel. Nach dessen Tode besorgt von Johannes Roediger und August Mueller. Leipzig, 1871-1872.

2. Serikoff N. I. Why did Ibn an-Nadim begin the Compilation of Kitab al-Fihrist? In: Sedov A. V. (ed.). Studies on Arabia and Islam. Moscow: GMV; 2014, pp. 456-473. (In Russ.).

3. Yarkho V. N. Kadm. In: Tokarev A. S. (ed.). Myths of the World. Encyclopaedia. Moscow: Sovetskaya Entsiklopediya; 1987. Vol. 1, pp. 607. (In Russ.).

4. Bayard Dodge. The Fihrist of al-Nadim: A Tenth-Century Survey of Islamic Culture. New York: Columbia University Press; 1970.

5. Alon I. Socrates in Medieval Arabic Literature. Leiden: Bril; 1991.

6. Serikoff N. I. About the exact meaning of the title of "Kitab al-Fihrist" by Ibn an-Nadim. A hitherto unrecorded Greek and Arabic parallel expression. In: 
Dziewanowski-Petrasczhewski V. M. (ed.). A Gift for the Scholars and Comfort for the Enlighted. St Petersburg: Peterburgskoe vostokovedenie; 2016, pp. 41-61. (In Russ.).

7. Yau K. C. Analysis of pre-telescopic and telescopic sunspot observations. In: Stephenson F. R., Wolfendale A. W. (eds). Secular Solar and Geomagnetic Variations in the last 10000 years. Durham; 1987.

8. Das Pyramidenbuch des Abu Ga`far al-Idrisi, eingel. und kritisch hrsg. v. U. Haarmann. Beirut; 1991 (BTS 38) 63.1 cp. ZDMG 13(1859).

9. Serikoff N. I. Words with hidden meaning. From the note-book by Patriarch Makariyus ibn az-Zaim. Khristianskii Vostok. 2001;3(IX):297-307. (In Russ.).

10. Lemerle P. Le premier humanisme byzantin: notes et remarques sur enseignement et culture à Byzance des origines au Xe siècle. Paris; 1971.

11. Kazhdan A. (ed.). Oxford Dictionary of Byzantium. Oxford; 1991.

12. Gainsford T. (ed.). Georgii Choerobosci Dictata in Theodosii Canones, Necnon Epimerismi in Psalmos. Vol. 1. Oxford; 1842.

13. Merx A. Historia artis grammaticae apud Syros. Leipzig; 1889.

14. Farina M. Diathesis and middle voice in the Syriac ancient grammatical tradition: The translations and adaptations of the Téchne Grammatiké and the Arabic model. Aramaic Studies. 2008;6(2):175-193. DOI: 10.1163/147783508X393039.

15. Jagić Y. Codex slovenicus rerum grammaticarum. Berlin; 1896.

16. Messina G. Al-Biruni and the Beginning of Christianity at Merv. Indo-Iranica. 1952;5(4):49-56.

17. Parry K. Byzantine-Rite Christians (Melkites) in Central Asia in Late Antiquity and the Middle Ages. Modern Greek Studies. 2012;16:91-108.

18. Klein W. Das orthodoxe katholikat von Romagyris in Zentralasien. Parole de l'Orient. 2010;24(1999):235-265.

19. Brock S. Two Letters of the Patriarch Timothy from the Late Eighth Century on Translations from Greek Arabic Science and Philosophy. 1999;9(2):233-246. DOI: 10.1017/S0957423900001338.

20. Treiger A. Palestinian Origenism and the Early History of the Maronites: In Search of the Origins of the Arabic Theology of Aristotle In: Janos D. (ed.). Ideas in Motion in Baghdad and Beyond: Philosophical and Theological Exchangesbetween Christians and Muslims in the Third/Ninth and Fourth/Tenth Centuries. Leiden; 2015, pp. 44-80.

21. Serikoff N. I. The Greek Verbal Lemmas from the Lexicon by Bar Bahlul, their Origin and the Lost Work by Hunayn ibn Ishaq "Principles of i'rāb / According to the Greek Scholars”. Orientalistica. 2018;1(1):45-65. (In Russ.) DOI: 10.31696/26187043-2018-1-1-45-65.

22. Hassan bar Bahlul. Lexicon Syriacum. Parisiis; 1901.

23. Robins R. H. The Byzantine Grammarians. Their Place in History. Berlin; New York; 1993.

24. Versteegh C. H. M. Greek Elements in Arabic linguistic thinking. Leiden; 1977.

25. Gainsford T. (ed.). Georgii Choerobosci Dictata in Theodosii Canones, Necnon Epimerismi in Psalmos Vol. 3. Oxford; 1842. 
26. Gardthausen V. Die Namen der Griechischen Schriftarten. Byzantinischneugriechische Jahrbücher. 1922;3:1-15.

27. Trapp E. Lexikon zur byzantinischen Gräzität. Byzantinische Zeitschrift; 2007.

28. Payne Smith R. (ed.). Thesaurus Syriacus. Oxford; 1879.

29. Thompson E. M. An Introduction to Greek and Latin palaeography. Oxford; 1912.

30. Kuehn C. G. (ed.). Galeni Opera Omnia. Vol. 19. Lipsiae; 1830.

31. Boudon-Millot V. Galien. Tome I. Introduction générale. Sur l'ordre de ses propres livres. Sur ses propres livres. Que l'excellent médecin est aussi philosophe. Texte établi, traduit et annoté par V. B.-M. Paris: Les Belles Lettres; 2007.

32. Lebedev V. V. A Grammar of Arabic. An outline. In Russian and Arabic Moscow: Muravei; 2003. (In Russ.)

\section{Информация об авторе}

Сериков Николай Игоревич, кандидат исторических наук, Институт востоковедения РАН, г. Москва, Российская Федерация.

\section{Раскрытие информации о конфликте интересов}

Автор заявляет об отсутствии конфликта интересов.

\section{Информация о статье}

Поступила в редакцию: 19 декабря 2018 г. Одобрена рецензентами: 16 января 2019 г. Принята к публикации: 7 февраля 2019 г.

\section{Information about the author}

Nikolaj I. Serikoff, Ph. D (Hist.), Institute of Oriental Studies, Russian Academy of Sciences, Moscow, Russian Federation.

\section{Conflicts of Interest Disclosure}

The author declares that there is no conflict of interest. 